
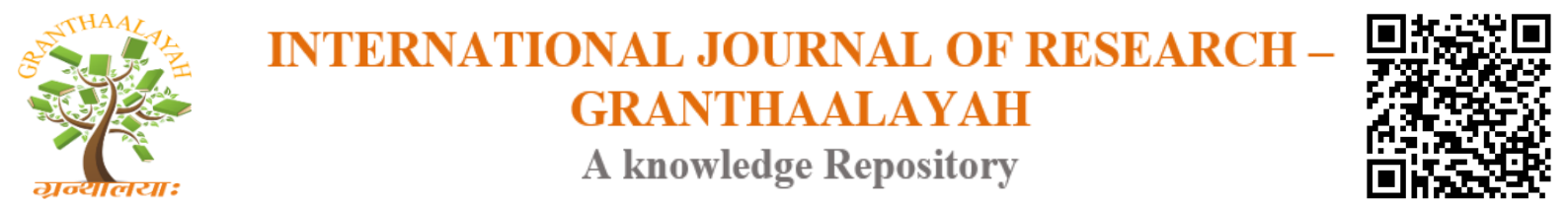

Science

\title{
EUTROPHICATION IN THE LOWER COASTAL BASIN OF THE JAMAPA RIVER IN VERACRUZ, MEXICO
}

\author{
María del Refugio Castañeda-Chávez ${ }^{1}$, Cinthya A Sosa-Villalobos ${ }^{* 1}$, Isabel A Amaro- \\ Espejo $^{1}$, Itzel Galaviz-Villa ${ }^{1}$, Fabiola Lango-Reynoso ${ }^{1}$ \\ ${ }^{*}$ División de Estudios de Posgrado e Investigación, Tecnológico Nacional de México/Instituto
}

Tecnológico de Boca del Rio

\begin{abstract}
The aim of this study was to determine parameters of dissolved oxygen, temperature and nitrogen in the coastal basin of the Jamapa River as indicators of eutrophication. Six sampling sites were selected in the lower basin, where samples were collected in triplicate in each site, during three seasons; north winds, dry and rainy. Results of the research, analyzed using the Minitab statistical program, were: site 2 showing the maximum value of dissolved oxygen with $5.83 \mathrm{mg} / \mathrm{L}$; site 5 with the maximum temperature value of $30.3{ }^{\circ} \mathrm{C}$, during the dry season. Whereas, maximum mean values of total nitrogen were at site $2(4.596 \mathrm{mg} / \mathrm{L})$ and site $5(4.281$ $\mathrm{mg} / \mathrm{L})$. Coastal basins can change markedly the nitrogen concentration with respect to weather and environmental conditions. As well as, reduced forms of nitrogen cause alterations in dissolved oxygen and the increase in water temperature, along with high concentrations of nutrients.
\end{abstract}

Keywords: Temperature; Rivers; Dissolved Oxygen; Total Nitrogen; Eutrophying.

Cite This Article: María del Refugio Castañeda-Chávez, Cinthya A Sosa-Villalobos, Isabel A Amaro-Espejo, Itzel Galaviz-Villa, and Fabiola Lango-Reynoso. (2017). "EUTROPHICATION IN THE LOWER COASTAL BASIN OF THE JAMAPA RIVER IN VERACRUZ, MEXICO.” International Journal of Research - Granthaalayah, 5(12), 206-216. https:// doi.org/10.29121/granthaalayah.v5.i12.2017.495.

\section{Introduction}

The state of Veracruz is characterized by having a high volume of water resources with respect to other entities of the Mexican Republic. (1). It has a wide coastline, which allows for extensive activities related to the use of coastal and marine resources mainly (2). Due to its characteristics and limits of hydrological basins, four hydrological regions from north to south have been established and delimited by the National Water Commission: RH-26 Pánuco, RH-27 north of Veracruz or Tuxpan-Nautla, RH-28 Papaloapan and RH-29 Coatzacoalcos. The region analyzed for this study is included in the Papalopan river basin, particularly in the Jamapa river. This river is formed by two important currents, which at their confluence are known by the names of 
Cotaxtla and Jamapa rivers. At the end of their route, they flow into the Gulf of Mexico, through Boca del Río, Veracruz (3). The coastal and fluvial reliefs are the most dynamic among the different types of terrestrial forms, being vulnerable to erosion, and flooding, which results in several impacts such as sea level rise, storm surge and displacement of the coastline.

It is important to take advantage of geomorphological cartography to carry out water quality studies to assess damage in coastal areas vulnerable to natural forces such as floods, cyclones and anthropogenic discharges (4). The quality of water in basins is a direct result of the incorporation of chemical compounds, ions and gases received through air and soil, from the biological, socioeconomic, geochemical and physical processes that transform these paths $(5,6)$. Nutrients and contaminants are naturally incorporated into aquatic and terrestrial ecosystems, however anthropic influence has altered these cycles by increasing their concentration $(7,8)$.

Water bodies often exceed the capacity for natural assimilation, so the quality of the resulting water is unacceptable. This situation compromises the states and the regulating entities of water quality control in coastal basins: to establish policies, that limit discharges to water sources and to regulate the quality of water by applying norms that establish the permissible limits of the control parameters for the protection of natural water resources (9). However, the reality is inadmissible, in terms of complying with the quality standards of the discharges, it is required to have wastewater treatment plants that comply with an efficient sanitary management. In addition, there are systematic limitations in the control of quality parameters (10). The objective of this study was to analyze water quality in the lower basin of the Jamapa River for three seasons, evaluating parameters of dissolved oxygen, temperature and total nitrogen as an effect of eutrophication by discharges and runoff that is received as a result of productive activities.

\section{Materials and Methods}

\subsection{Study Site and Location of Sampling Sites}

The study was carried out in the Jamapa river basin, whose area covers the municipalities of Medellín, Boca del Río and Alvarado (latitudes from 19.1250 to 19.050 and lengths from 96.180 to -96.100$)$ (11). The location of the sampling sites is indicated in Figure 1.

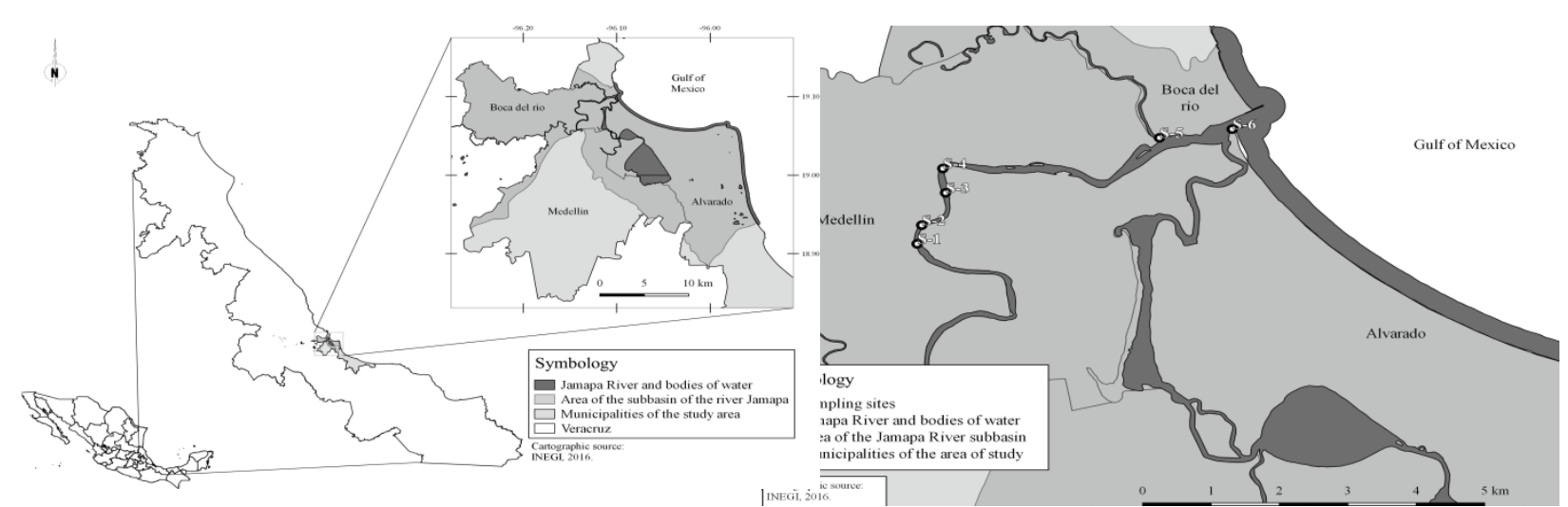

Figure 1: Location of the study area and location of the sampling sites in the lower coastal basin of the Jamapa River, Veracruz, Mexico. 
Sand deposition processes predomínate in the lower basin of the Jamapa River, interspersed with the formation of dune fields that run transversely and/or parallel to the coastline that go inland. The relief is classified as low plains and hills that belong to the subprovince coastal plain of Veracruz (12). Six sampling sites were selected in the lower basin of the Jamapa River as a result of a survey study. Important discharge areas were identified in these sites, including human settlements and different production activities. Among other important discharges that this basin receives, there are three units of aquaculture production and that of a thermoelectric plant. Also, in the study area was marked as a public interest sampling site, the Moreno stream discharge, which is characterized as a municipal effluent that comes from the cities of Veracruz and Boca del Río. The mouth of the Jamapa River corresponds to the estuary influx area. This is in an area close to the sea and also to the discharge channel that feeds the important Mandinga lagoon system in Veracruz.

\subsection{Sampling and Analytical Methods}

The six selected sampling sites were georeferenced and water samples were taken at each site in a timely manner. Samples were taken in triplicate at each site in a morning schedule during the three seasons of an annual cycle. The seasons currently recognized, in the study region, are three during the year: north winds (November-February), dry (March-June) and rainy (July-October). A multiparameter probe model YSI-556 was used for in situ measurement of temperature and dissolved oxygen.

With respect to the total nitrogen analysis, the surface water samples were placed in labeled bottles, fixed with the addition of sulfuric acid until $\mathrm{pH} 2$ and kept in refrigerators at $4 \pm 1{ }^{\circ} \mathrm{C}$. They were transferred under a chain of custody until they reached the Water Resources Research Laboratory (LIRA) of the Technological Institute of Boca del Río (ITBOCA). Where the samples were analyzed, before 7 days of being refrigerated, by the technique of total nitrogen according to the Mexican standard NMX-AA-026 for waters, by Kjeldahl Method, published in the Official Gazette of the Federation on the 27th October, 1980 (13). This technique is in accordance with international standards and the (14).

A volume of $50 \mathrm{ml}$ of the sample was used, placed in a Kjeldahl digestion flask with $10 \mathrm{ml}$ of accelerating reagent and boiling beads for digestion. The samples were placed in a hood for gas extraction and temperature control, until obtaining a clear light green solution, free of vapors. This process took approximately 20-30 minutes per sample. To begin with the distillation step, the digested sample was allowed to cool, then distilled water was added until reaching a total volume of $50 \mathrm{ml}$ in the flask. In the distillation equipment, a $20 \mathrm{ml}$ solution of sodium hydroxide $(\mathrm{NaOH})$ was added to neutralize the digested sample until the color changes from light to dark. To receive the distillate, an Erlenmeyer flask was placed in the nitrogen distillation equipment to which $75 \mathrm{ml}$ of boric acid solution and 2 or 3 drops of mixed indicator were added. Making sure that the tip of the condenser remained totally submerged inside the boric acid, the sample was distilled until obtaining a volume of approximately $200 \mathrm{ml}$. The presence of ammonia changes the color of the boric acid solution from blue to green, when the indicator has been used. The digested sample was allowed to cool and distilled water was added until reaching a total volume of $50 \mathrm{ml}$ in the flask in the distillation equipment, a solution of $20 \mathrm{ml}$ of sodium hydroxide was added to neutralize the digested sample until a change of light to dark color was obtained. To 
receive the distillate, an Erlenmeyer flask was placed in the nitrogen distillation equipment to which $75 \mathrm{ml}$ of boric acid solution and 2 or 3 drops of mixed indicator were added. Attention was paid to the fact that the tip of the condenser remained totally immersed inside the boric acid, the sample was distilled until obtaining a volume of approximately $150 \mathrm{ml}$. When the indicator has been used, the presence of ammonia changes the color of the boric acid solution from blue to green. For the titration process, the distillate volume was titrated with the sulfuric acid standard at $0.02 \mathrm{~N}$ until the indicator changes to a pale pink color. During the process, a reagent blank and a known concentration standard of phenylamine were made to determine the yield and recovery percentage of the method.

\subsection{Statistic analysis}

For the process of the measured variables, an analysis of variance (ANOVA) was performed between the sampling sites and the seasons. The Tukey test (HSD) with a confidence interval of $95 \%$ ( $p<0.05$ ) was used in order to compare the differences between groups. The analyzes were performed using the Minitab statistical program (v.17, Minitab Inc.)

\section{Results and Discussions}

\subsection{Dissolved Oxygen}

Dissolved oxygen is an indicator par excellence, which defines the quality of water for aquatic life (15). The results of the dissolved oxygen (DO) samples analyzed in the six chosen sites, during the three seasons, indicated a mean minimum value of $4.5 \mathrm{mg} \mathrm{L}^{-1}$ in Site 5 and a mean maximum value of $5.83 \mathrm{mg} \mathrm{L}^{-1}$ in Site 2 . In the statistical analysis by seasons, the following mean values were found: dry season: $5.63 \mathrm{mg} \mathrm{L}^{-1}$, rainy season: $5.35 \mathrm{mg} \mathrm{L}^{-1}$ and north winds season: $5.55 \mathrm{mg} \mathrm{L}^{-1}$ (Figure 2).

According to the EPA (16) and the ecological criteria of the European community (CE-CCA001/89)(17), levels of dissolved oxygen concentration are established with values of 4.5 and 5 $\mathrm{mg} / \mathrm{L}$ of DO for the supply of potable water for agricultural irrigation and protection of coastal areas, respectively.The following values are also included: for the protection of aquatic life in fresh and marine water $5 \mathrm{mg} \mathrm{L}^{-1}$ of DO, for the development of species for aquaculture: tilapia $2.1 \mathrm{mg} \mathrm{L}^{-1}$, carp $5 \mathrm{mg} \mathrm{L}^{-1}$, catfish $4 \mathrm{mg} \mathrm{L}^{-1}$ and trout $7.8 \mathrm{mg} \mathrm{L}^{-1}$. Most fish tolerate a low concentration of dissolved oxygen for a certain period of time. However, concentrations below the percentage of saturation produce negative effects on biodiversity, growth, reproduction and their activity. The results obtained from this study are superior to the limits established by the EPA and CE-CCA-001/89 for the supply, as well as for the protection of aquatic life, they were: Site 1 of $6.40 \mathrm{mg} \mathrm{L}^{-1}$ and Site 2 of $6.10 \mathrm{mg} \mathrm{L}^{-1}$, in the rainy season. A maximum value was obtained at Site 3 of $7.20 \mathrm{mg} \mathrm{L}^{-1}$ during the dry season. In an investigation carried out by Torres et al. (18), water quality was determined in the Seco river in one of the sampling sites of the area called "La Concha", where $7.3 \mathrm{mg} \mathrm{L}^{-1}$ of OD was obtained in the rainy season, approximate value to that of this study in the Jamapa river. Therefore, these two rivers of the state of Veracruz show anthropogenic influences that alter the OD in the water. 
95\% for the mean value

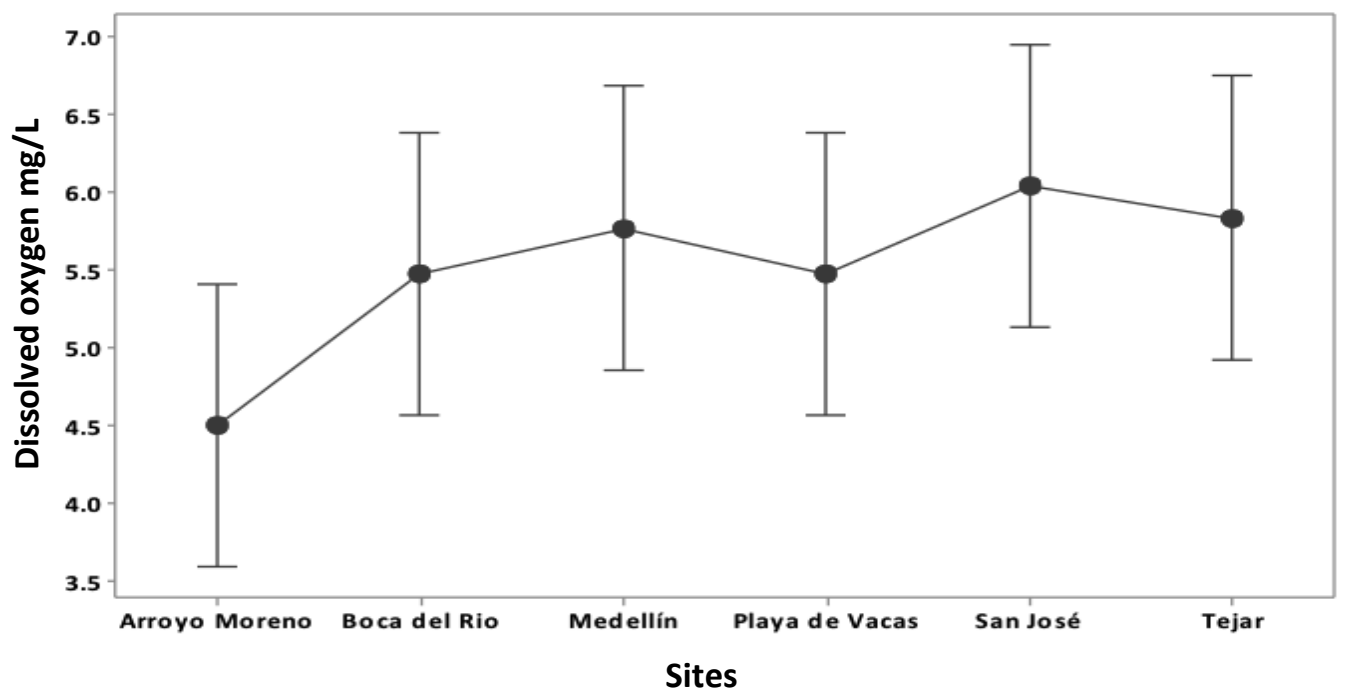

Figure 2: Evolution of dissolved oxygen concentration by sampling sites in the lower coastal basin of the Jamapa River, Veracruz, Mexico.

Almazán et al. (19), conducted a study that indicated that during the rainy season in the channel of the Papagayo River, Guerrero, Mexico, an average of $6.42 \mathrm{mg} \mathrm{L}^{-1}$ and $3.98 \mathrm{mg} \mathrm{L}^{-1}$ of OD were obtained, in dry and rainy season respectively, which demonstrated the decrease of OD in the rainy season. However, in the study of the Jamapa River, no significant statistical differences were found in both seasons.

Sandoval et al. (20) conducted a study to assess the current condition of the Atoyac River, between the states of Puebla and Tlaxcala in Mexico, based in the river sub-basin, during the dry season, the DO measurement was in a range of $1.7 \mathrm{mg} \mathrm{L}^{-1}$ to $6.4 \mathrm{mg} \mathrm{L}^{-1}$. According to Hernández (21), the oxygen needs vary for different uses, where the minimum value of $2 \mathrm{mg} \mathrm{L}^{-1}$ is for recreational use and the maximum value of $7 \mathrm{mg} \mathrm{L}^{-1}$ can be used for the reproduction of salmonids.

\subsection{Temperature}

Mean and minimum temperature values were analyzed by sites in this study. The results were: Site $1,27.5{ }^{\circ} \mathrm{C}$, which was the minimum value and the maximum was $30.3^{\circ} \mathrm{C}$ in Site 5 (Figure 3 ). Bain (22), indicated the dependence of dissolved oxygen concentration with respect to water temperature, after relating both parameters. According to different studies, authors point out that the temperature of running water is one of the most important parameters in studies of aquatic ecosystems, it influences chemical processes present in river systems, as well as conditions and biological behavior (23). The change in water temperature generates changes in the composition of species as well as in reproduction processes, putting at risk the structure of the marine trophic network. Also, the increase in temperature causes an increase in the level of eutrophication (24, 23) 

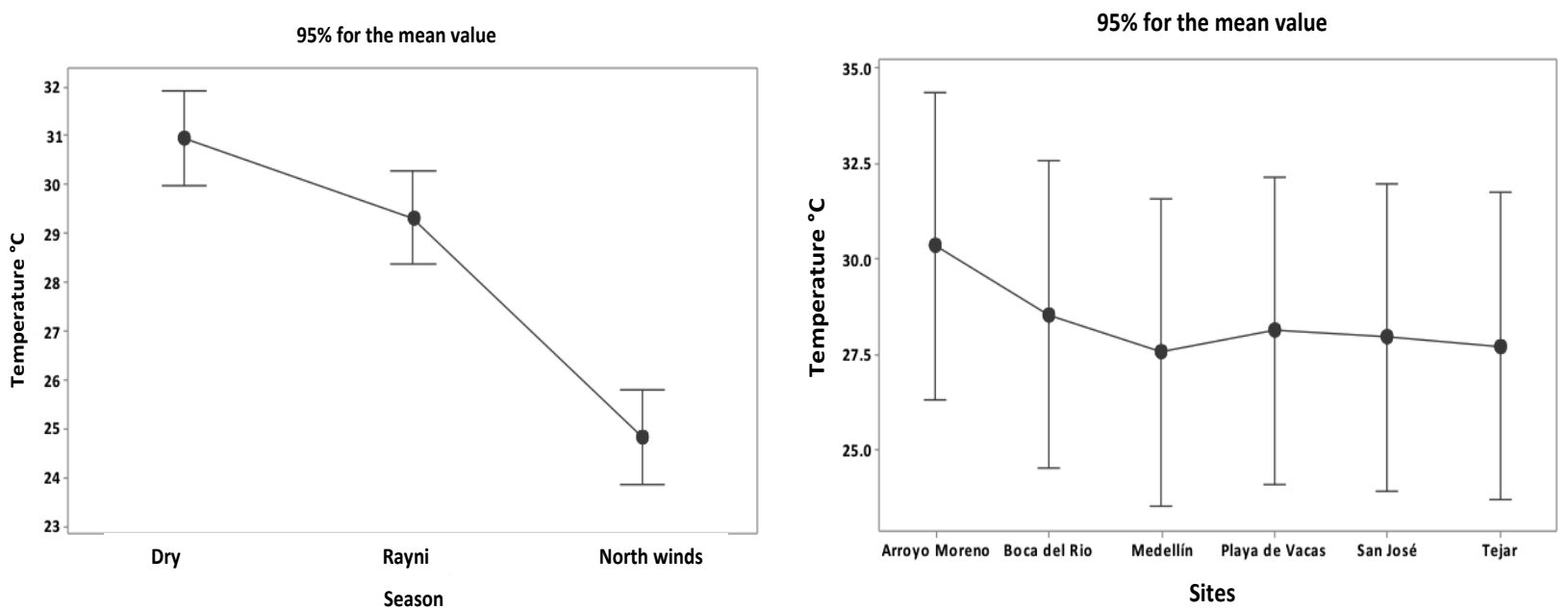

Figure 3: Temperature evolution by sampling sites and seasons in the lower basin of the Jamapa River, Veracruz, Mexico.

In this study, the statistical analysis of the temperature parameter did not present a significant difference. The following mean values were reported: $30.93{ }^{\circ} \mathrm{C}$ in the dry season, $29.32{ }^{\circ} \mathrm{C}$ in the rainy season and $24.82^{\circ} \mathrm{C}$ during the north winds season (Figure 3 ). The statistical analysis indicated that there was a significant difference in the measurement of temperature by seasons, specifically in the north winds against the dry of $6^{\circ} \mathrm{C}$ and with respect to the rainy season of 4.5 ${ }^{\circ} \mathrm{C}$. Ridanovic et al. (25), noted in their study on the Neretva River, that the temperature difference between seasons is considerable and this may influence the processes of the aquatic environment, particularly dissolved oxygen concentrations. The temperature of the water varies with the change of seasons. In addition, in a study conducted by Almazán et al. (19) in the Papagayo River, a temperature mean value of all the sampling sites of 30.31 and $29.9{ }^{\circ} \mathrm{C}$ was obtained in the dry and rainy season, respectively. What refers to values similar to the study of the Jamapa River. Smith et al. (26) indicated that the concentration of dissolved oxygen in surface waters varies greatly with respect to temperature, because the level of saturation in the water decreases when the water temperature increases.

\subsection{Total Nitrogen}

The presence of nitrogen in the water resource is of vital importance due to environmental and sanitary consequences, such as: increased acidity, eutrophication and toxicity of aquatic ecosystems, which ultimately affect the survival, growth and reproductive capacity of aquatic organisms and terrestrial (27). Mean results of the parameters analyzed by sites are indicated in Table 1.

Table 1: Sampling sites and mean values of disolved oxygen, temperature and total nitrogen.

\begin{tabular}{lllll}
\hline $\begin{array}{l}\text { Key } \\
\text { Site }(\mathbf{S})\end{array}$ & $\begin{array}{l}\text { Sampling } \\
\text { site }\end{array}$ & $\begin{array}{l}\text { Dissolved } \\
\text { oxygen } \\
\mathbf{m g}^{-\mathbf{L}}\end{array}$ & $\begin{array}{l}\text { Temperature } \\
\mathbf{o}^{\mathbf{0}} \mathbf{C}\end{array}$ & $\begin{array}{l}\text { Total nitrogen } \\
\mathbf{m g ~ L}^{-\mathbf{1}}\end{array}$ \\
\hline S1 & Medellín & $6.19 \pm 0.728$ & $27.67 \pm 2.36$ & $3.353 \pm 1.095$ \\
S2 & Tejar & $5.96 \pm 0.489$ & $27.89 \pm 2.27$ & $4.596 \pm 2.012$ \\
S3 & San José & $5.92 \pm 0.698$ & $27.94 \pm 2.41$ & $3.858 \pm 2.287$
\end{tabular}




\begin{tabular}{lllll} 
S4 & Playa de vacas & $5.67 \pm 0.437$ & $28.12 \pm 2.42$ & $2.732 \pm 1.201$ \\
S5 & Arroyo Moreno & $3.41 \pm 0.694$ & $30.30 \pm 2.74$ & $4.281 \pm 2.391$ \\
S6 & Boca del Río & $5.74 \pm 0.330$ & $29.04 \pm 2.72$ & $3.384 \pm 1.676$ \\
\hline
\end{tabular}

A coastal basin presents equilibrium conditions in the concentration of oxygen when it does not present problems of eutrophication, that is, the surface waters contain high concentrations of dissolved oxygen and the concentration of nitrogen is in the form of nitrates, a compound that is of low toxicity with respect to to other forms of nitrogen (28).

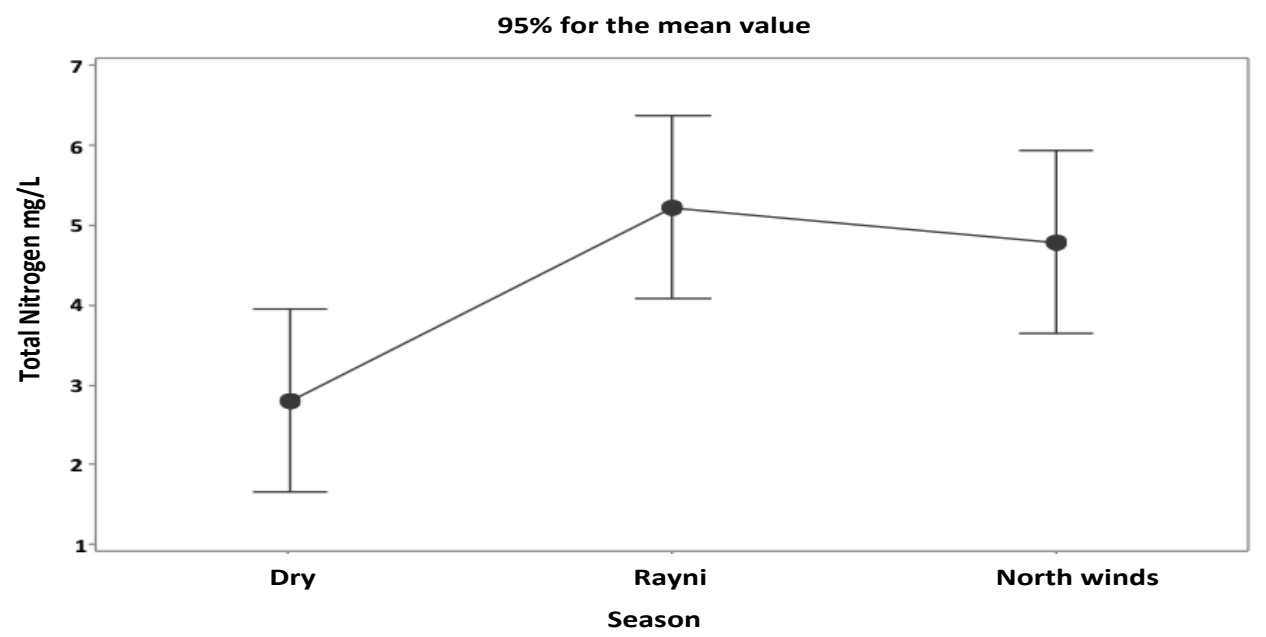

Figure 4: Total nitrogen sampling sites during the year, in the lower basin of the Jamapa River, Veracruz, Mexico.

The maximum mean values reported in this study were present at site $2(4,596 \pm 2,012)$ and site $5(4,281 \pm 2,391)$. The statistical analysis did not show significant differences in the analyzed sites. This, according to studies reported by other authors $(29,30)$, indicates that there is influence in both sites as a consequence of the presence of this nutrient (Figure 4).

The nitrogen content in greater concentration has its origin in different agricultural fertilizers, in waste originated by livestock activities and by municipal waters. Currently, the waters of rivers receive high levels of nutrients, which is a consequence of the different erosion processes, as well as of the different industrial and urban activities (31). Another source of nitrogen income to the ecosystem is through the atmosphere, by dry air currents and by precipitation. This has an impact on the biogeochemical cycles of coastal systems (32). The nutrients deposited by the atmospheric route, mainly by nitrogen, are potentially significant (33). This is related to the increase in the nitrogen concentration of $2.8 \mathrm{mg} \mathrm{L}^{-1}$ during the dry season, $4.8 \mathrm{mg} \mathrm{L}^{-1}$ in the north winds season and for the rainy season to concentrations of $5.3 \mathrm{mg} \mathrm{L}^{-1}$, this with respect to the dry season. The above can initiate the eutrophication of ecosystems, by producing various ecological and toxicological effects, which are directly or indirectly related to the proliferation of primary producers. This proliferation and its subsequent death and decomposition, usually lead to a marked decrease in the concentration of dissolved oxygen in those ecosystems with a reduced rate of water renewal $(34,35)$. 
The contribution of nitrogen in the river basins is of diffuse origin and represents more than $50 \%$ of the total basin (36). According to the anthropogenic nitrogen emissions, this compound can contribute to contamination, levels within the range of $0.5-1.0$ of total nitrogen $\mathrm{mg} \mathrm{L}^{-1}$ are considered. This range of concentrations seems relatively low, in relation to the high concentrations of nitrogen compounds reported in all sampling sites in this study area. According to Cárdenas-Calvachi \& Sánchez-Ortiz (27), the nitrogen monitoring in water is, therefore, an indicator element for the protection of public health and biota.

\section{Conclusions and Recommendations}

The relationship between dissolved oxygen and temperature indicates water quality. Although dissolved oxygen is essential for aquatic life, this study shows that in the different sampling sites and by season there were no significant differences, however the dissolved oxygen remained above the established by the ecological criteria of water quality in the General Law of Ecological Balance, as well as by the Environmental Protection Agency (EPA). On the other hand, temperature results showed significant differences in the north winds season. It is necessary to perform a constant monitoring of these parameters in sites adjacent to areas of residential housing discharges, among other point sources that indicate the possible effects due to the influence of population growth and the increase of productive activities in the study area.

Currently, the deterioration of water quality is a problem that is increasing, and is considered one of the main environmental problems. One of the main impacts, both for fresh and salt water, is the uncontrolled dumping of urban and industrial wastewater, often without treatment, as well as poor agricultural practices. Both, agricultural, livestock and urban activities are the result of different productive processes that are carried out at national level, impacting water bodies. Coastal basins can change in a marked way the concentration of nitrogen with respect to weather and environmental conditions. Massive deaths of fish and other aquatic organisms in coastal watersheds are indicators of hypoxia or anoxia in eutrophic and hypertrophic ecosystems that undergo stratification. The loss of habitat for the survival and reproduction of aquatic organisms can be a consequence of the lack of oxygen. As well as the reduced forms of nitrogen cause alterations in dissolved oxygen and increase in water temperature, along with high concentrations of nutrients; nitrogen is one of the essential elements for algae, its excess can produce processes of eutrophication in the basins.

\section{References}

[1] Houbron, E. (2010) 'Calidad del agua' In: Florescano, E. and Ortíz, J. (coord.), Atlas del patrimonio natural, histórico y cultural de Veracruz, México: Gobierno del Estado de Veracruz: Comisión del Estado de Veracruz para la Conmemoración de la Independencia Nacional y la Revolución Mexicana: Universidad Veracruzana. Veracruz, México.

[2] Ortiz, L., Arceo, P., Granados, A., Salas, D. and Jiménez, M.L. (2010), 'Zona Costera'. In: Florescano E and Ortíz J (coord.) Atlas del patrimonio natural, histórico y cultural de Veracruz, México: Gobierno del Estado de Veracruz: Comisión del Estado de Veracruz para la Conmemoración de la Independencia Nacional y la Revolución Mexicana: Universidad Veracruzana. Veracruz, México.

[3] Pereyra, D, Pérez, J. and Salas, M. (2010), 'Hidrología' In: Florescano E and Ortíz J (coord.) Atlas del patrimonio natural, histórico y cultural de Veracruz, México: Gobierno del Estado de 
Veracruz: Comisión del Estado de Veracruz para la Conmemoración de la Independencia Nacional y la Revolución Mexicana: Universidad Veracruzana. Veracruz, México.

[4] Tapas-Ranjan, M., Mohan-Vamsee, A. and Vinod-Kumar, K. (2016) 'Identification of vulnerable coastal zones-An approach through semi-automatic geomorphological mapping using satellite images', Conference: In: TROPMET 2016, At Bhubaneswar, Odisha, India

[5] Murdoch, P.S., Baron, J.S. and Miller, T.L. (2000),' Potential effects of climate change on surface-water quality in North America', Journal of the American Water Resources Association, Vol. 36, No. 2, pp. 347-366.

[6] Manahan, S.E. (2004) 'Environmental Chemistry', CRC Press. Edición 8. Boca Ratón, Florida. $783 \mathrm{pp}$.

[7] Kraemer, A.R., Choundhury, K. and Kampa, E. (2001), 'Protecting Water Resources: Pollution Prevention, Thematic Background Paper.' In: International Conference on Freshwater Bonn 2001. Secretariat of the International Conference on Freshwater Bonn (http//: www.water2001.de)

[8] Bleckner, T. (2006)' Sensitivity of freshwater ecosystems for climate change impacts. In: International Workshop on climate change Impacts on the Water Cycle', Resources and Quality, 25 -26 septiembre. Brussels

[9] Becerra-Pérez, M., Sáinz-Santamaría, J. and Muñoz-Piña, C. (2006) 'Los conflictos por agua en México. Diagnóstico y análisis' Gestión y Política Pública, Vol. XV, No. 1, pp. 111-143. http://www.redalyc.org/pdf/133/13315104.pdf

[10] Armas-Blancas, A.S. (2015) 'Simulación de la calidad del agua en ríos utilizando el modelo QUAL2EU', pp. 244-269 México. DOI:10.13140/RG.2.1.1976.5603

[11] Instituto Nacional de Estadística y Geografía (2016) 'Cartografía del estado de Veracruz'

[12] Palomarez, G.M. (2010), 'Valoración de la calidad de los influentes y efluentes de las granjas acuícolas de la Cuenca Baja del Río Jamapa, Veracruz', PhD thesis, Colegio de Postgraduados, Veracruz, México

[13] Norma Mexicana NMX-AA-026-SCFI-2010, 'Análisis de agua. Medición de Nitrógeno Total Kjeldahl en aguas naturales, residuales y residuales tratadas- Método de prueba'

[14] APHA (2005) 'Standard Methods for the Examination of Water and Wastewater', Clesceri L.S., Greenberg A.E., Eaton A.D. (Eds.) American Public Health Association, American Water Works Association and Water Environment Federation. 21st ed. 1325 pp.

[15] Kannel, P.R., Lee, S., Kanel, S.R. and Khan, S.P. (2007) 'Application of Water Quality Indices and Dissolved Oxygen as Indicators for River Water Classification and Urban Impact Assessment', Environmental Monitoring and Assessment, Vol.132, No. 1-3, pp. 93-110. DOI:10.1007/s10661-006-9505-1

[16] EPA (United States Environmental Protection Agency) (1986) 'National Recommended Water Quality Criteria. https://www.epa.gov/wqc/national-recommended-water-quality-criteria-aquaticlife-criteria-table'

[17] Criterios Ecológicos de Calidad de Aguas CE-CCA-001/89. Acuerdo por el que se establecen los Criterios Ecológicos de Calidad de Aguas en el Diario Oficial de la Federación (DOF) el 13/12/1989.

[18] Torres, B.B., González, L.G., Rustrián, P.E. and Houbron, E. (2013) 'Enfoque de cuenca para la identificación de fuentes de contaminación y evaluación de la calidad de un río, Veracruz, México', Revista Internacional de Contaminación Ambiental, Vol. 29, No. 3, pp. 135-146, 2013. http://www.redalyc.org/pdf/370/37028276001.pdf

[19] Almazán-Juárez, M.T., Almazán-Juárez, A., Carreto-Pérez, B.E., Hernández-Castro, E., DamianNava, A. and Almazán-Núñez, C.R. (2016) 'Calidad y clasificación de usos del agua en la cuenca baja del río Papagayo, Guerrero, México', Ecosistemas y Recursos Agropecuarios. Vol. 3, No. 9, pp. 293-305. http://www.scielo.org.mx/pdf/era/v3n9/2007-901X-era-3-09-00293.pdf 
[20] Sandoval-Villasana, A.M., Pulido-Flores, G., Monks, S., Gordillo-Martínez, A.J. and VillegasVollareal, E.C. (2009), Evaluación fisicoquímica, microbiológica y toxicológica de la degradación ambiental del río Atoyac, México', Interciencia, Vol. 34, No.12, pp. 880-887. https://www.uaeh.edu.mx/investigacion/icbi/LI_Helmintos/Griselda_Pulido/sandoval2009a.pdf

[21] Hernández-Muñoz, A. (1998) 'Depuración de aguas residuales', Colegio de Ingenieros de Caminos, Canales y Puertos. Colección Seinor. Editorial Paraninfo. Madrid, 1006 pp

[22] Bain, M. (1999). Interpreting Chemical Data. In: Bain M. and Stevenson N (ed). Aquatic Habitat Assessment: Common Methods. American Fisheries Society. Bethesda, Maryland.

[23] Bates, B.C., Kundzewicz, Z.W., Wu, S. and Palutikof, J.P. (Eds) (2008) 'Climate Change and Water. Technical Paper of the Intergovernmental Panel on Climate Change', IPCC Secretariat, Geneva, $210 \mathrm{pp}$

[24] Hoepffner, N., Dowell, M.D., Edwards, M., Fonda-Umani, S., Green, D.R., Greenaway, B., Hansen, B., Heinze, C, Leppänen, J.M., Lipiatou, E., Özsoy, E., Philipart, C.J.M., Salomons, W., Sanchez-Arcilla, A, Schrimpf, W., Schrum, C., Theocaris, A., Tsimplis, M., Veloso-Gomes, F., Wakenhut, F. and Zaldivar, J.M. (2006) 'Marine and Coastal Dimension of Climate Change in Europe'. A report to the European Water Directors. Institute for Environment and Sustainability, Joint Research Centre, European Commission. EUR 22554 EN.

[25] Ridanovic, L., Ridanovic, S., Jurica, S. and Spasojevic, P. (2010), 'Evaluation of Water Temperature and Dissolved Oxygen Regimes in River Neretva', In: BALWOIS 2010 - Ohrid, Republic of Macedonia - 25, 29 May 2010

[26] Smith, R.A., Alexander, R.B. and Lanfear, K.J. (1993). Stream water quality in the conterminous United States- Status and trends of selected indicators during the 1980's. In: U.S. Geological Survey, Water Supply Paper 2400, Reston, Virginia https://water.usgs.gov/nwsum/sal/trends.html

[27] Cárdenas-Calvachi, G.L. and Sánchez-Ortiz, I.A. (2013) 'Nitrógeno en aguas residuales: Orígenes, efectos y mecanismos de remoción para preservar el ambiente y la salud pública', Universidad y Salud, Vol. 15, No. 1, pp. 72-88.

http://www.scielo.org.co/scielo.php?script=sci_arttext\&pid=S012471072013000100007\&lng=en \&tlng=es.

[28] Guzmán-Quintero, A., Palacios-Vélez, O.L., Carrillo-González, R., Chávez-Morales, J., Nikolskii-Gavrilov, I. (2007) 'La contaminación del agua superficial en la cuenca del río Texcoco, México', Agrociencia, pp. 385-393. http://www.redalyc.org/articulo.oa?id=30241402

[29] Camargo, J., Alonso, A., Salamaca, A. (2005) 'Nitrate toxicity to aquatic animals: a review with new data for freshwater invertebrates', Chemosphere, Vol. 58, No. 9, pp. 1255-1267. DOI:10.1016/j.chemosphere.2004.10.044

[30] Camargo, J. and Alonso, A. (2007) 'Contaminación por nitrógeno inorgánico en los ecosistemas acuáticos: problemas medioambientales, criterios de calidad del agua, e implicaciones del cambio climático', Revista Ecosistemas, Vol. 16, No. 2. https://rua.ua.es/dspace/bitstream/10045/7673/1/ECO_16(2)_11.pdf

[31] Pettine, M., Casentini, B., Fazi, S., Giovanardi, F. and Pagnotta, R. (2007) 'A revisitation of TRIX for trophic status assessment in the Light of the European Water 239 Framework Directive: Application to Italian coastal waters', Marine Pollution Bulletin, Vol. 54, pp. 14131426.DOI:10.1016/j.marpolbul.2007.05.013

[32] Oyarzñun, C.E., Godoy, R. and Leiva, S. (2002), 'Depositación atmosférica de nitrógeno en un transecto Valle Longitudinal - Cordillera de los Andes, centro-sur de Chile', Revista Chilena de Historia Natural, Vol. 75, pp. 233-243.

[33] Frohn, L.M. and Hertel, O. (2005) 'Atmospherical deposition of nutrients. In: Wassmann P and Olli K (Eds). Drainage basin nutrient inputs and eutrophication: an integrated approach', Norwegian College of Fishery Sciences, University of Troms $\varnothing$, Troms $\varnothing$, Norway. Tartu University, Department of Botany and Ecology. Estonia. 
[34] Glibert, P.M., Seitzinger, S., Heil, C.A., Burkholder, J.M., Parrow, M.W., Codispoti, L.A. and Kelly, V (2005) 'The role of eutrophication in the global proliferation of harmful algal blooms: new perspectives and new approaches' Oceanography, Vol.18, No. 2, pp. 198-209 http://dx.doi.org/10.5670/oceanog.2005.54

[35] Andersen, J.H., Schlüter, L. and Ærtebjerg, G. (2006) 'Coastal eutrophication: recent developments in definitions and implications for monitoring strategies', Journal of Plankton Research, Vol. 28, pp. 621-628. https://doi.org/10.1093/plankt/fbl001

[36] Álvarez, C.R., Álvarez, R. and Steinbach, H. (2000) 'Predictions of Available Nitrogen Content in Soil Profile Depth Using Available Nitrogen Concentration in Surface Layer', Communications in Soil Science and Plant Analysis, Vol. 32, pp. 759-769. https://doi.org/10.1081/CSS-100103907

\footnotetext{
*Corresponding author.

E-mail address: ca.sosavi@gmail.com
} 